\title{
The Effect of Job Characteristics on Managers' Intent to Leave the Organization: The Mediating Role of the Four Dimensions of Organizational Commitment
}

\author{
Fouzia $\mathrm{Ali}^{1}$ \\ ${ }^{1}$ Hailey College of Commerce, University of the Punjab, Pakistan \\ Correspondence: Fouzia Ali, Hailey College of Commerce, University of the Punjab, Pakistan. E-mail: \\ fouziaalihcc@gmail.com
}

Received: March 24, 2015

Accepted: April 7, 2015

Online Published: May 22, 2015

doi:10.5539/ijbm.v10n6p239

URL: http://dx.doi.org/10.5539/ijbm.v10n6p239

\begin{abstract}
The primary purpose of the study was to investigate the effect of job-related characteristics on the employees' intent to leave the organization. In order to accomplish this purpose a survey questionnaire was adapted and administered to 750 employees of various commercial banks of Pakistan. Out of the 750 questionnaires administered 700 were received with a response rate of $93.33 \%$. Structural Equation Modeling was applied using AMOS 16 software. The results revealed a highly significant effect of job characteristics on intent to leave the organization in the presence of the mediation of the four dimensions of organizational commitment. The results can prove to be useful for the human resource managers to review the job description and revise or redesign the job characteristics that would help the organizations to retain employees in the organization.
\end{abstract}

Keywords: job characteristics (JC), continuance commitment-perceived sacrifice (CC-PS), continuance commitment-lack of alternatives (CC-L Alt) and normative commitment (NC) and intent to leave (ITL)

\section{Introduction}

In an ever-changing environment it has become a challenge for organizations to run successfully. In order to face such challenges it has become inevitably important to have employees who feel to continue and work as a moral obligation for the betterment and success of an organization. Although the employees may move elsewhere if they get a better opportunity as it's their right but the point to be considered is the financial set-back on the organizations investing a lot of resources on training their workforce (Ali, 2011). Additionally, with the help of bringing improvements in the working conditions the organizations can create a psychological bond and commitment amongst the employees (Al-Qarioti \& Al-Enezi, 2004). As far as bringing improvement in the working conditions is concerned the organization require diagnostics that might prove helpful in identifying those features within a job that need to be enriched and to assess whether employees in an organization are willing to respond positively to the changes made in their respective tasks (Boonzaier, Ficker, \& Rust, 2001). Moreover, in times when organizations are confronted with a greater necessity to bring changes, employees who are committed to their organizations can facilitate in adopting the changes within the organization (Schuster, 2002). Therefore, in order to enhance the organizational effectiveness it is essential to improve the team efforts of committed employees (Angle \& Perry, 1981).

Organizations like commercial banks are considered to be the biggest employment providing sector in Pakistan, yet it is the most stressed out sector also. The inefficient use of technology and long working hours are considered to be the prime reasons for employees' lack of commitment. Although being the most attractive employment sector for the young workforce due to the problems faced by the employees after joining has result in a decline in the level of commitment of employees which in turn has lead to either turnover by switching one bank to the other or seeking to other opportunities which lead to turnover intentions. Therefore, it is vital to study the job-related characteristics of such employees that may trigger the commitment level of employees which would in turn stimulate their intentions to leave the organization. 


\section{Literature Review}

\subsection{Job Characteristics (JC)}

Hackman and Oldham in 1975, developed a Job Diagnostic Survey (JDS) to assess the job-related characteristics of employees that could assist in understanding the key role such characteristics play in understanding how employees perceive about their work in the organization. Such factors of JDS have been considered to be helpful in highlighting those key areas in the job that can assist in increasing the level of commitment of employees (Buys, Olckers, \& Schaap, 2007). The JDS comprise of five factors, such as, (a) task identity, which is the degree to which an employee is identified with his/her job, (b) task significance, which is the extent to which others in the organization are affected by the work accomplished by an employee, (c) skill variety, which is the extent to which an employee is required to perform different tasks, (d) autonomy, which is the extent to which an employee has been granted freedom to accomplish the work assigned, and (d) feedback, which is the extent to which an employee wants to know how he/she is performing his/her job.

\subsection{Organizational Commitment (OC)}

Meyer and Allen (1997) defined organizational commitment as 'a psychological link between the employee and his or her organization that makes it less likely that the employee will voluntarily leave the organization' (p. 252) Similarly, Robbins (1999) has defined commitment as, 'the extent to which an employee identifies with a particular organization and its goals and wishes to maintain membership in the organization'. This definition highlights three distinct components that are, the employee accepts the goals of the organization; he/she is prepared to exert an extra effort for achieving the goals set by the organization; and, the desire to continue an association in the organization. Furthermore, the term organizational commitment refers to the employees' overall feelings and extent of attachment toward their organization (Bartlett, 2001).

With respect to the dimensionality of the organizational commitment construct, Meyer and Allen (1991) identified three dimensions of Organizational commitment i.e., affective, continuance and normative commitment. As far as affective commitment is concerned it has been defined as an "attitudinal process whereby people come to think about their relationship with the organization in terms of the values they hold that are in line with the organizational aims and values, they work in" (Meyer \& Allen, 1991).

Moreover, with respect to continuance commitment it has been decribed as the intent of an employee to stay in the organization (Meyer \& Allen, 1991). In this regard some researchers (Dawley, Houghton, \& Bucklew, 2010; Iverson \& Buttigieg, 1999; Lynn, 2004; McGee \& Ford, 1987; Somers, 1995; Vandenberghe \& Panaccio, 2012) have identified continuance commitment to have two sub-dimensions. This concept of continuance commitment is based on the scarcity of alternatives and a sacrifice of management role such as seniority which he might not get if he quits the job. In this regard, it is argued that the perceived sacrifice dimension is a psychological state that allows an employee to put in more efforts while accomplishing his tasks which in turn is more resourceful. In contrast lack of alternatives results in less efforts the employee exerts and lack of motivation which in turn can be called as drainage of resourcefulness (Vandenberghe \& Panaccio, 2012). These two sub-dimensions of continuance commitment have been studied less due to lack of evidence (Dunham, Grube, \& Casteneda, 1994; Price, 1999; Shore \& Tetrick, 1991). Furthermore, there is a scarcity of literature in studying the two sub-dimensions of continuance commitment in a wider perspective by relating them with different variables.

Lastly, with respect to normative commitment as a componenet of organizational commitment, Meyer and Allen (1991) defined normative commitment that, "is a moral dimension, based on person's felt obligation and responsibility to their organization". In this regard they argued that employees with a high level of normative commitment will remain associated with the organization with a sense of what they feel the right and moral thing to do.

\subsection{Intent to Leave (ITL)}

Intent to leave can be considered as a conscious desire to leave the organization (Mobley, Horner, \& Hollingsworth, 1978). Furthermore, several studies have assessed the three elements of withdrawal cognition process - which are thoughts of quitting, the intention to search for another job somewhere else and the conscious feeling to quit (Carmeli \& Weisberg, 2006; Cho, Johanson, \& Guchait, 2009; Hom \& Griffeth, 1991). The current study focuses on the investigation of intent to leave for several reasons. Most of the literature does not clearly specify always that why employees quit their jobs. The records of the organization might provide information about the number of employees quitting their jobs but do not specify the break-up of voluntary and involuntary turnovers (Thompson \& Terening, 1983). In this regard if in case the turnover records are unclear, the findings of various studies based on such records would also remain ambiguous as voluntary turnover has 
different impact on the organization as compared to involuntary turnover. Furthermore, investigations relating to the employees' intent to leave could be completed earlier as the employees are still members of the organization rather than waiting for employees to be terminated and then gather information (Thompson \& Terening, 1983). Moreover, since intention leave can be the best predictor to assess actual turnover so efforts should be made to assess the association of this concept with other variables which might prove to be the predictors (Igbaria \& Greenhaus, 1992).

\subsection{Relationships among Job Characteristics, Organizational Commitment and Intent to Leave}

As far as investigating the relationship of job characteristics with all the dimensions of organizational commitment is concerned it has been revealed that job characteristics have a positive relationship with organizational commitment (Dunham et al., 1994).Yet in a recent study, Ozturk, Hancer, and Im (2014) revealed that only two factors, namely, autonomy and feedback have a significant effect on affective commitment. Similarly, many other studies (Bulan, Erickson, \& Wharton, 1997; Colbert \& Kwon, 2000 ; Steers, 1977) also revealed a positive association with organizational commitment but not with all the factors of job characteristics. In this regard, two factors (i.e., task variety and task significance) of job characteristics depict a significant positive relationship with the two dimensions of organizational commitment (i.e., affective and normative commitment) (Ali, 2011; Ozturk et al., 2014). With respect to the factor of task identity it showed a positive relationship with affective and continuance commitment (Ozturk et al., 2014). Furthermore, autonomy which is one of the factors of job characteristics also revealed a significant positive association with continuance commitment. Lastly, with respect to feedback which is also an important factor of job characteristics revealed a highly significant positive association with normative commitment (Ozturk et al., 2014).

Furthermore, employees' intention to leave can be described as, the employees' subjective opinion about the intention to leave the organization (Mowday, Porter, \& Steers, 1982). In this regard it has been observed that there is a significant negative relationship between job characteristics and employees' intent to leave. This shows that the more variety the task possess, greater the task identity and the more autonomy the employee has the lesser the employee would intend to leave the organization (Ali, 2011).

Although a number of studies have reported a highly significant relationship among different job characteristics and the dimensions of organizational commitment still the effects of such relationship with outcomes such as intent to leave is scarce (Colbert \& Kwon, 2000 ; Ozturk et al., 2014).

\subsection{The Mediating Role of Organizational Commitment between the Effects of Job Characteristics on Employees' Intent to Leave}

With respect to the mediating role of the dimensions of organizational commitment between the effect of job characteristics and intent to leave the organization, gaps have been identified in the literature. Lee and Kim (2008) asserted that in order to improve the quality of work-life and reduce the turnover intentions of employees there is a need to increase the autonomy which is necessary for industrial democracy. Therefore, there is always a need to enrich the jobs so that employee commitment could be enhanced and resultantly the employees' intention to leave can be reduced (Lee \& Kim, 2008). Additionally, most of the prevailing literature has been confined to the study of relating job characteristics to the three dimensions (i.e., affective, continuance and normative) of organizational commitment. In this regard there is an absence of literature on identifying the two sub-dimensions (i.e., perceived sacrifice-PS and Lack of Alternatives-L Alt) of continuance commitment and investigating the mediating role of each sub-dimension of continuance commitment. Therefore the current study tries to investigate the indirect effects of job characteristics on the intent to leave the organization with the mediation of the four dimensions of organizational commitment. 


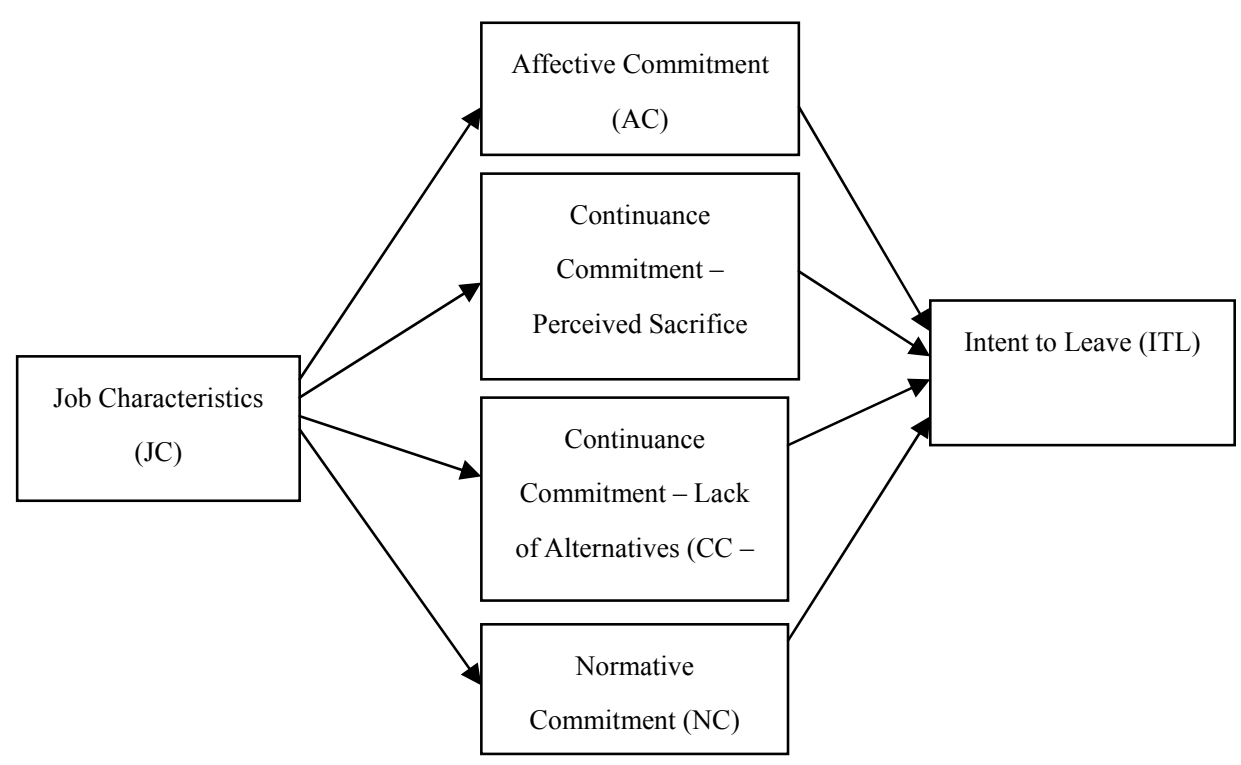

Figure 1. Proposed model

The above Figure 1 shows the mediating role of the four dimensions of organizational commitment while investigating the effect of job characteristics on the employees' intention to leave the organization. In light of the theoretical model the current study intends to investigate the direct and indirect effects of the multiple mediation model. In order to accomplish this objective several hypotheses were developed and tested.

\section{Hypotheses of the Study}

The current study testified the following hypotheses:

$\boldsymbol{H}_{1}$ : There is a significant effect of job characteristics on employees' intent to leave the organization with a mediation of affective commitment.

$\boldsymbol{H}_{2}$ : There is a significant effect of job characteristics on employees' intent to leave the organization with a mediation of continuance commitment-perceived sacrifice.

$\boldsymbol{H}_{3}$ : There is a significant effect of job characteristics on employees' intent to leave the organization with a mediation of continuance commitment-lack of alternatives.

$\boldsymbol{H}_{4}$ : There is a significant effect of job characteristics on employees' intent to leave the organization with a mediation of normative commitment.

The above hypotheses have been developed to study the indirect effect of the mediating role of each dimension of organizational commitment while studying the effect of job characteristics on employees' intent to leave the organization.

\section{Methodology}

\subsection{Sampling Design and Procedure}

A survey based on a questionnaire was conducted collecting responses from 750 managers employed in Pakistani banking sector. The rationale behind selecting commercial banks was due to the fact that the banking sector is one of the leading financial sectors of Pakistan. In the last decade new private banks have been established which have created a large pool of employment opportunities. Other than that due to the creation of greater opportunities it has been observed there has been a phenomenal switching over of the employees from one bank to the other. This had created a big question as to why such turnover has increased. Therefore, manager-level employees were chosen from 26 banks by employing convenience sampling. The reason behind selecting convenience sampling design was to provide an equal opportunity for participation in the study (Babbie, 1989). The benefits of using this approach are firstly, the availability of greater number of potential participants for the study and, secondly the non-availability avoidance of the respondents if systematic or stratified sampling method was used. Therefore, a total of 750 questionnaires were administered after seeking permission from the branch managers with a response rate of $93.33 \%$. The demographic information showed that $89 \%$ as males and 
$12 \%$ as females. $70 \%$ of the respondents had an education of Masters Degree and $67 \%$ respondents had more than five years experience in working in the current bank.

Furthermore, the bank managers were divided according to the level of management (lower, middle and higher level) and nature of bank (public, private and Islamic).

\subsection{Instrument Development}

The responses were collected on a five-point Likert-scale (i.e. strongly agree, agree, neither agree nor disagree, disagree and strongly disagree). The items were taken from different scales developed by prior researchers. As far as items relating to organizational commitment is concerned a measure using 18 items developed by Meyer and Allen (1997) was used. In this regard the 6 items related to each of the dimension i.e., affective commitment, continuance commitment and normative commitment). Moreover, 13 items of job characteristics were taken from (Hackman \& Oldham, 1975) and 3 items relating to turnover intention were selected from scale developed by (Hom \& Griffeth, 1991). The reliabilities (Cronbach Alphas) of these items were Affective Commitment (0.693), Continuance Commitment (0.584), Normative Commitment (0.781), Job Characteristics (0.941) and Intention to leave (0.827).

\subsection{Data Analyses}

In order to calculate the descriptive statistics (such as, Mean, Standard Deviations and reliability coefficients) SPSS 16 software was used. Moreover, One-way Analysis of Variance (ANOVA) was employed to seek differences among the managers at different levels and the perceptions they hold about task variety, task identity, task significance, autonomy and feedback. Similarly, ANOVA was also applied to examine the differences in the perception among the managers relating to different nature (public, private and Islamic) about the task variety, task identity, task significance, autonomy and feedback. Furthermore, descriptive analysis was conducted to apply Pearson correlation in order to assess the relationships among the independent variable, mediating variables and dependent variable. Furthermore, Analysis of Moments Structures (AMOS 16) software was used to test the mediating model and examine the direct and indirect effects of job characteristics on employees' intent to leave.

\section{Results and Findings}

\subsection{Descriptive Analysis}

Table 1 depicts the means, standard deviations and correlations among the six variables (Job Characteristics, Affective Commitment, Continuance Commitment-PS, Continuance Commitment-L Alt, Normative Commitment and Intent to leave). The mean scores for variables on a five-point scale were as follows: Job characteristics $2.81(\mathrm{SD}=0.97)$, Affective commitment $2.78(\mathrm{SD}=1.09)$, Continuance commitment-Perceived Sacrifice (PS) 2.91 (SD = 1.04), Continuance commitment-Lack of Alternatives (L Alt) 2.98 ( $\mathrm{SD}=0.70$ ), Normative commitment $2.80(\mathrm{SD}=0.95)$ and Intent to Leave $3.09(\mathrm{SD}=0.95)$.

\subsection{Correlation Analyses}

The correlation results as shown in Table 1, revealed highly positive significant relationship between job characteristics and affective commitment $(\mathrm{r}=0.79, \mathrm{p}<0.001)$. Moreover, the results also showed highly significant positive relationship between job characteristics and continuance commitment-Perceived Sacrifice ( $\mathrm{r}$ $=0.44, \mathrm{p}<0.001)$. Similar results were revealed with respect to the relationship between job characteristics and continuance commitment - Lack of alternatives $(r=0.70, p<0.001)$ and with normative commitment $(r=0.74$, $\mathrm{p}<0.001)$. On the other hand the correlation results revealed a highly significant negative relationship between job characteristics and employees intent to leave the organization $(r=-0.41, p<0.001)$.

Table 1. The means, standard deviations and correlations of variables

\begin{tabular}{|c|c|c|c|c|c|c|c|c|c|}
\hline & Variables & Mean & $\mathrm{SD}$ & 1 & 2 & 3 & 4 & 5 & 6 \\
\hline 1 & Job Characteristics & 2.81 & 0.97 & 1 & & & & & \\
\hline 2 & Affective Commitment & 2.78 & 1.09 & $0.79 * *$ & 1 & & & & \\
\hline 3 & Continuance Commitment - PS & 2.91 & 1.04 & $0.44 * *$ & $0.52 * *$ & 1 & & & \\
\hline 4 & Continuance Commitment - L Alt & 2.98 & 0.70 & $0.26^{* *}$ & $0.21 * *$ & $0.24 * *$ & 1 & & \\
\hline 5 & Normative Commitment & 2.80 & 0.95 & $0.70^{* *}$ & $0.74 * *$ & $0.56^{* *}$ & $0.25 * *$ & 1 & \\
\hline 6 & Intent to Leave & 3.09 & 1.01 & $-0.41 * *$ & $-0.50 * *$ & $-0.38 * *$ & .047 & $-0.52 * *$ & 1 \\
\hline
\end{tabular}




\subsection{Comparison of Perceptions Relating to the Job Characteristics among Lower, Middle and Higher Level Managers}

In order to compare the perceptions among managers working at different levels One -Way Analysis of Variance (ANOVA) was applied Table 2 below shows the difference in the perceptions relating to skill variety, task identity, task significance, autonomy and feedback. Furthermore, Post Hoc analysis was applied to examine and highlight the differences among the groups.

Table 2. The means, standard deviations and differences in perceptions

\begin{tabular}{|c|c|c|c|c|c|c|c|c|}
\hline \multirow[t]{2}{*}{ Variables } & \multicolumn{2}{|c|}{ Lower-Level Managers } & \multicolumn{2}{|c|}{$\begin{array}{l}\text { Middle-Level } \\
\text { Managers }\end{array}$} & \multicolumn{2}{|c|}{$\begin{array}{l}\text { Higher-Level } \\
\text { Managers }\end{array}$} & \multirow[t]{2}{*}{ F-value } & \multirow{2}{*}{$\begin{array}{l}\text { Level of } \\
\text { Sig. }\end{array}$} \\
\hline & Mean & $\mathrm{SD}$ & Mean & $\mathrm{SD}$ & Mean & $\mathrm{SD}$ & & \\
\hline Skill Variety & 2.65 & 0.98 & 3.02 & 1.02 & 2.71 & 1.05 & 8.41 & $.000 * * *$ \\
\hline Task Identity & 2.50 & 0.98 & 2.99 & 1.02 & 2.68 & .98 & 12.20 & $.000 * * *$ \\
\hline Task Significance & 2.63 & 1.02 & 2.97 & 1.10 & 2.59 & 1.10 & 8.98 & $.000 * * *$ \\
\hline Autonomy & 2.74 & 1.20 & 3.07 & 1.29 & 2.77 & 1.19 & 4.91 & $.008^{* *}$ \\
\hline Feedback & 2.50 & 1.09 & 2.98 & 1.12 & 2.64 & 1.10 & 9.851 & $.000 * * *$ \\
\hline
\end{tabular}

Note. $* * \mathrm{p}<.05, * * * \mathrm{p}=.000$.

The results revealed highly significant difference $(F=8.41, p=0.00)$ in the perception of different level of managers with respect to skill variety. Moreover the post hoc results showed a significant difference in the perceptions about the skill variety among middle level managers as compared to both lower level managers and higher level managers. With respect to perceptions relating to the task identity a highly significant difference $(\mathrm{F}=$ $12.20, p=0.000)$ was identified. The post hoc results revealed a significant difference in perception about the task identity of middle level managers as compared to both the lower level managers and higher level managers. The results also revealed a significant difference $(\mathrm{F}=8.98, \mathrm{p}<0.05)$ in the perceptions about task significance among different level of managers. The post hoc results revealed that the there is a difference in the perception relating to task significance among middle level managers as compared to both the lower level and higher level managers. Moreover, a significant difference $(\mathrm{F}=4.91, \mathrm{p}=0.00)$ was observed among the different level managers with respect to autonomy. The post hoc tests revealed middle level managers have a significant difference in terms of autonomy as compared to lower level managers and higher level managers. Lastly, a highly significant difference $(\mathrm{F}=9.85, \mathrm{p}=0.00)$ in the perceptions among the managers working at different levels was identified with respect to feedback. The post hoc tests revealed that there is a difference in the perception of middle level managers about the feedback as compared to lower and higher level managers.

5.4 Comparison of Perceptions Relating to the Job Characteristics among Public, Private and Islamic Bank Managers

In order to compare the perceptions among managers working in different banks, One-Way Analysis of Variance (ANOVA) was applied Table 3 below shows the difference in the perceptions relating to skill variety, task identity, task significance, autonomy and feedback. Furthermore, Post Hoc analysis was applied to examine and highlight the differences among the groups.

Table 3. The means, standard deviations and differences in perceptions

\begin{tabular}{|c|c|c|c|c|c|c|c|c|}
\hline \multirow[t]{2}{*}{ Variables } & \multicolumn{2}{|c|}{ Public Bank Managers } & \multicolumn{2}{|c|}{ Private Bank Managers } & $\begin{array}{l}\text { Islami } \\
\text { Manag }\end{array}$ & Bank & \multirow[t]{2}{*}{ F-value } & \multirow{2}{*}{$\begin{array}{l}\text { Level } \\
\text { Sig. }\end{array}$} \\
\hline & Mean & SD & Mean & SD & Mean & $\mathrm{SD}$ & & \\
\hline Skill Variety & 2.67 & 1.04 & 2.82 & 1.02 & 3.24 & .91 & 4.15 & $0.016^{* *}$ \\
\hline Task Identity & 2.76 & 1.10 & 2.73 & 0.98 & 3.37 & .89 & 7.74 & $0.000 * * *$ \\
\hline Task Significance & 2.78 & 1.12 & 2.70 & 1.08 & 3.39 & 1.00 & 7.63 & $0.001 * *$ \\
\hline Autonomy & 2.76 & 1.33 & 2.87 & 1.23 & 3.41 & 1.12 & 4.16 & $.016^{* *}$ \\
\hline Feedback & 2.78 & 1.17 & 2.69 & 1.09 & 3.45 & 1.03 & 8.93 & $.000 * * *$ \\
\hline
\end{tabular}

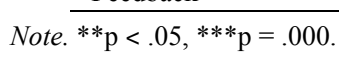

The results revealed highly significant difference $(F=4.15, p<.05)$ in the perception of different level of 
managers with respect to skill variety. Moreover the post hoc results showed a significant difference in the perceptions about the skill variety among Islamic bank managers as compared to both public and private managers. With respect to perceptions relating to the task identity a highly significant difference $(\mathrm{F}=7.74, \mathrm{p}=$ 0.000 ) was identified. The post hoc results revealed a significant difference in perception about the task identity of Islamic bank managers as compared to both the private and public managers. The results also revealed a significant difference $(\mathrm{F}=7.63, \mathrm{p}<0.05)$ in the perceptions about task significance among managers relating to different banks. The post hoc results revealed that the there is a difference in the perception relating to task significance among Islamic bank managers as compared to both the public and private managers. Moreover, a significant difference $(\mathrm{F}=4.16, \mathrm{p}<0.05)$ was observed among the managers relating to different banks with respect to autonomy. The post hoc tests revealed that Islamic bank managers have a significant difference in terms of autonomy as compared to public and private banks. Lastly, a highly significant difference $(\mathrm{F}=8.93, \mathrm{p}=$ 0.00 ) in the perceptions among the managers working at different levels was identified with respect to feedback. The post hoc tests revealed that there is a difference in the perception of Islamic Bank managers about the feedback as compared to public and private bank managers.

\subsection{Mediation Analyses}

The purpose to conduct a structural equation analysis was to evaluate the conceptual model empirically. In this respect affective commitment which is a dimension of organizational commitment had to be removed as model was unidentified. Consequently the first hypothesis that had to testify the mediation effect of affective commitment between the effect of job characteristics and intent to leave was removed from the study. Furthermore, all the items relating to job characteristics were collectively studied in the mediation model in order to get a clearer insight of its effect on intent to leave. After re-specifying the model the analysis showed a good fit of the model. Figure 2, shows the path diagram of the mediation model. The results showed the RMSEA i.e. root mean square of error approximation value $=.067$ and CFI value i.e. comparative fit index $=0.910$.

With respect to the direct and indirect effects of job characteristics on intent to leave the results revealed:

\section{a) The Effect of Job characteristics on Intent to Leave via-Continuance Commitment-Perceived Sacrifice(PS)}

Table 2 shows the direct effect of job characteristics (JC) on intent to leave (ITL) which was significant (pc $=$ $0.23, \mathrm{p}=0.05$ ). Moreover, the indirect effects were estimated as the products of path coefficients of direct effects. Therefore, the indirect effect of job characteristics (JC) on intent to leave (ITL) via continuance commitment-perceived sacrifice (PS) was estimated by the product of job characteristics on continuance commitment-PS and Continuance commitment (PS) on intent to leave (ITL) which was equal to $(0.59) *(-0.21)=$ - 0.12. The indirect effect $(-0.12)$ was weaker than the direct effect $(0.23)$. This means the indirect effect of job characteristics on intent to leave was partially mediated by continuance commitment - PS (as $0.23>-0.12$ ). Therefore, the hypothesis: $\boldsymbol{H}_{\mathbf{2}}$ showing that there is a significant but partial effect of job characteristics on employees' intent to leave the organization with a mediation of continuance commitment - perceived sacrifice.

\section{b) The Effect of Job characteristics on Intent to Leave via-Continuance Commitment-Lack of Alternatives ( $L$ Alt)}

Table 2 shows the direct effect of job characteristics (JC) on intent to leave (ITL) which was significant (pc = $0.23, \mathrm{p}=0.05$ ). Moreover, the indirect effects were estimated as the products of path coefficients of the direct effects. Therefore, the indirect of job characteristics (JC) on intent to leave (ITL) via continuance commitment-lack of alternatives (L Alt) was calculated through the product of job characteristics on continuance commitment-L Alt and Continuance commitment -- L Alt on intent to leave (ITL) which was $(0.35) *(0.30)=0.11$. The indirect effect $(0.11)$ was weaker than the direct effect $(0.23)$. This means the indirect effect of job characteristics on intent to leave was partially mediated by continuance commitment-L Alt (as $0.23>$ 0.11). Therefore, the hypothesis: $\boldsymbol{H} \mathbf{3}$ showing that there is a significant but partial effect of job characteristics on employees' intent to leave the organization with a mediation of continuance commitment-lack of alternatives.

\section{c) The Effect of Job characteristics on Intent to Leave via-Normative Commitment}

Table 2 shows the direct effect of job characteristics (JC) on intent to leave (ITL) which was significant (pc = $0.23, \mathrm{p}=0.05)$. The indirect effects were estimated as products of the path coefficients of direct effects. Therefore, the indirect of job characteristics (JC) on intent to leave (ITL) via normative commitment was calculated through the product of job characteristics on normative commitment and normative commitment on intent to leave (ITL) which was $(0.88)^{*}(-0.73)=-0.64$. The indirect effect $(-0.64)$ was stronger than the direct effect (0.23)This means the indirect effect of job characteristics on intent to leave was fully mediated by 
normative commitment (as $0.23<-0.64$ ). Therefore, the hypothesis: $\boldsymbol{H}_{4}$ showing that there is a significant but full effect of job characteristics on employees' intent to leave the organization with a mediation of normative commitment.

Table 4. Standardized indirect effects of job characteristics (JC) on intention to leave (ITL)

\begin{tabular}{llll}
\hline $\begin{array}{l}\text { Effects } \\
\text { ITL JC }\end{array}$ & Standardized Path Coefficients (pc) & BC 95\% Level of significance & $\begin{array}{l}\text { Result } \\
\text { Mediation }\end{array}$ \\
\hline Direct & 0.23 & $.050^{*}$ & \multicolumn{1}{c}{ of } \\
\hline Indirect: & & Sobel Z-test & Partial \\
\hline Continuance Commitment -- PS & $(0.59)(-0.21)=-0.12$ & $-4.68^{* * *}$ & Partial \\
Continuance Commitment - L Alt & $(0.35)(0.30)=0.11$ & $3.46^{* * *}$ & Full \\
Normative Commitment & $(0.88)(-0.73)=-0.64$ & $-4.171^{* * *}$ & \\
\hline
\end{tabular}

Note. ${ }^{* * *}$ Significant at $\mathrm{p}<0.001$.

Figure 2, below shows the standardized path coefficients of the mediation model.

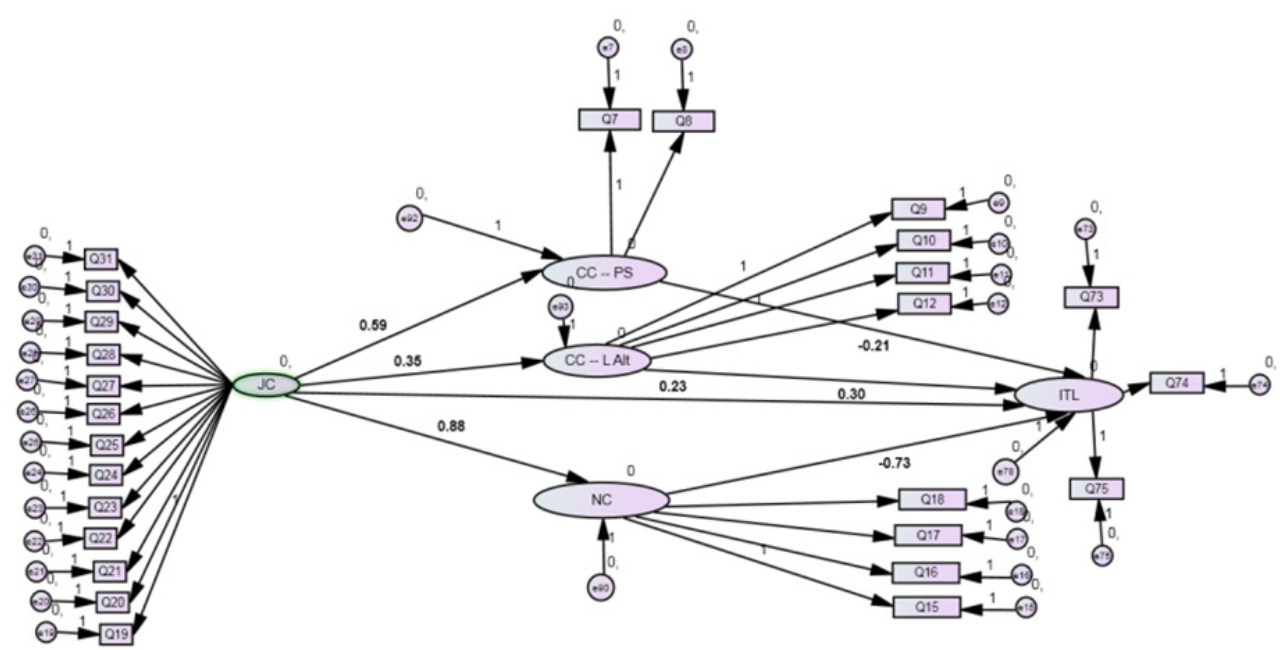

Figure 2. Path diagram of the mediating model

\section{Discussion}

\subsection{Correlation Analyses}

The correlation coefficients revealed through the data analyses, among affective commitment, continuance commitment - perceived sacrifice, continuance commitment-lack of alternatives, normative commitment and intent to leave indicated the presence of linear associations among the variables. The correlation coefficients among the variables varied from 0.047 to 0.79 which showed that the relationships among the variables were considered moderate to high.

\subsection{Group Comparisons through ANOVA}

The comparison amongst the managers' perceptions about the job characteristics with respect to their level of management and nature of bank revealed interesting findings. In terms of the level of management it was revealed that the middle managers perceived that their job includes greater skill variety, task identity, task significance, autonomy and feedback as compared to the lower level and higher level managers. The reason would be due to the fact that lower level bank managers normally have to follow the same routine work and have less autonomy in accomplishing the tasks. As far as the higher level management is concerned it is much 
confined to the decision-making by developing goals and objectives. With respect to middle level managers they are actively participating in the operational activities and hence have greater variety of work and autonomy and since they are answerable to the higher management their communication channel is much more recognized as compared to lower level managers who are indulged in monotonous work.

With respect to the perceptions about the job characteristics among public, private and Islamic banks managers the results revealed that Islamic bank managers perceived differently about the skill variety, task identity, task significance, autonomy and feedback. This highlights a future investigation as to the differences in the job characteristics even though all the managers were related to the banking sector. The differences in tasks need to be further examined about why those differ in Islamic banks as compared to private and public banks.

\subsection{Mediation Analyses}

Job characteristics indicated a direct effect of 0.23 which was stronger than its indirect effect of -0.12 . The Sobel Z-test, revealed the indirect effect of the job characteristics on intent to leave via continuance commitment-PS as a mediator was significantly different from zero $(Z=-4.468, p<.001)$. In other words, continuance commitment as perceived sacrifice partially mediated the association between job characteristics and intention to leave. In other words, it can be inferred that the more job characteristics are aligned with the expectations of the employees in terms of task variety, task significance, autonomy and feedback, the higher the employee would perceive to continue with the organization in terms of perceived sacrifice that such characteristics of tasks might not be available in the new employing organization. This in turn will reduce the employees' intention to leave the organization.

Moreover, the examination of the mediation effect of job characteristics on intention to leave through continuance commitment-lack of alternatives indicated direct effect of 0.23 stronger than its indirect effect of 0.11. The Sobel Z-test revealed the indirect effect of job characteristics on intent to leave through the mediator was significantly different from zero $(Z=3.46, p<.001)$. This indicates that continuance commitment - lack of alternatives partially mediated the relationship between job characteristics and intention to leave. In other words even if the employee perceives that the job characteristics are signified and proper feedback and autonomy is given still he would continue to work in the organization due to lack of alternatives. Resultantly still such continuance due to lack of alternatives will increase the urge of an employee to leave the organization till the time he gets any other opportunity elsewhere.

Furthermore, the mediation analysis of normative commitment between job characteristics and intention to leave showed indirect effects of - 0.64 stronger than the direct effects of 0.23 . The Sobel Z-test revealed the indirect effect of job characteristics on the intent to leave in the presence of normative commitment as a mediator was significantly different from zero $(Z=-4.171, p<.001)$. This means that normative fully mediates the relationship between job characteristics and intent to leave. This means that the more an employee perceives that his job tasks are effective the greater he would feel morally obligated to continue with the current organization. This in turn will reduce the employees' intention to leave the organization.

In light of the above discussion it can be inferred that job characteristics effect the employees' continuance commitment associated with perceived sacrifice as it is a psychological state which allows an individual to put in more efforts (Vandenberghe \& Panaccio, 2012). Thus, such a continuance commitment is considered to be more resourceful as it induces the employees to work better and continue their membership with the organization especially if he perceives that the tasks given to him matches his expectations such as variety of tasks, task significance, autonomy in accomplishing various assignments and feedback about how he is performing at work. This would in turn reduce the employees' intention to leave the organization.

Moreover, job characteristics revealed a significant positive effect on continuance commitment which is associated with an individual's lack of alternative to move elsewhere. As this dimension of continuance commitment is linked with the drainage of resourcefulness therefore it can result in fewer efforts exerted in order to accomplish various tasks at work (Vandenberghe \& Panaccio, 2012). This shows that an employee may continue membership with the organization as he might know that the type of job characteristics he received from the current organization will not be the same in any other organization which resultantly shows lack of alternatives. Furthermore, it can be asserted that an employee would continue membership with the organization only because he does not have anywhere else to move so he would still be thinking to leave the organization.

Additionally, job characteristics also a highly significant negative effect on intent to leave with the indirect mediation of normative commitment. The reason for this outcome may be due to the fact that if the organization is providing the employee better job- related tasks such as, tasks having greater variety in terms of work and skills, significance, autonomy and feedback then it's his moral responsibility to reciprocate in the same manner 
and continue affiliation with the organization. This in turn would also reduce the employees' intent to leave the organization.

\section{Implication of the Study}

The current study provides a basis for several implications on the intent to leave the organization with the research findings from the interaction between job characteristics, intent to leave and its mediating factors that relate to organizational commitment. Firstly, the current study provides a basis for the policy-makers to design or adjust jobs in such a manner that could enable the employees to accomplish differing tasks in differing ways, provide authority so that they are able to complete tasks individually, given autonomy to accomplish tasks by taking decisions by themselves and provide feedback on how well they have accomplished their respective jobs. Secondly, this study provided a unified approach to assess the turnover intentions due to variations in the job characteristics through the mediating effect of the three dimensions of organizational commitment. Thirdly, by testing the dimensions of organizational commitment especially the two sub-dimensions ((i.e., perceived sacrifice and lack of alternatives) of continuance commitment and normative commitment as mediating variables provide new insights in the existing literature relating to management. Conclusively, these mediating dimensions of organizational successfully revealed their influence on the employees' intent to leave the organization.

\section{Limitations and Implications for Future Research}

The current study was subject to some limitations also. Firstly, since a questionnaire was used to seek responses so the study can have a self-reporting bias due to under statement or understatement. Secondly, this study used only one predictor i.e., job characteristics to study the effect on intent to leave with the mediation of the dimensions of organizational commitment. Other antecedents such as, perceived organizational support, organizational climate could be used to study their effects on the dimensions of organizational commitment that could provide more details in studying the varying nature of the employees' intent to leave the organization. Moreover, further investigations are required to examine the differences in the job characteristics in Islamic banks as perceived by the managers as compared to public and private banks although the nature of banking operations tend to be the same.

\section{Conclusions}

The main focus of the current research was to examine the level of employees' intention to leave in comparison with the independent variable in the presence of the involvement of the mediating variables. While answering all the hypotheses, the study was designed to observe the relationships of the independent, mediating and dependent variables. Firstly, Continuance commitment-Perceived sacrifice was studied as a mediating variable to reveal how this mediator explains the variance between job characteristics and employees' intent to leave. Continuance commitment-lack of alternatives and normative commitment followed the same path and helped predicting the effect of job characteristics on employees' intent to leave. All of the mediators except for affective commitment which had to be removed from the mediation model bridged a chain between the job characteristics and intent to leave through the dimensions of organizational commitment. The findings reveal the importance of the job characteristics as an actionable element in shaping up the commitment level of employees that would ultimately result in retaining the membership of employees with the organizations.

\section{References}

Ali, F. H. (2011). Organizational commitment and employees' intention to leave the organization in Banking industry of Pakistan. (MPhil), Univerity of the Punjab, Pakistan.

Al-Qarioti, M. Q. A., \& Al-Enezi, A. (2004). Organizational commitment of managers in Jordan: A field study. International Journal of Public Administration, 27(5), 331-352. http://dx.doi.org/10.1081/PAD-120028813

Angle, H. L., \& Perry, J. L. (1981). An empirical assessment of organizational commitment and organizational effectiveness. Administrative Sciences Quarterly, 26(1), 1-14.

Babbie, E. R. (1989). The Practice of Social Research (5th ed.). CA, USA: Wadsworth Publishing Company.

Bartlett, K. R. (2001). The relationship between training and organizational commitment: A study in the health care field. Human Resource Development Quarterly, 12(4), 335-352. http://dx.doi.org/10.1002/hrdq.1001

Boonzaier, B., Ficker, B., \& Rust, B. (2001). A review of research on the job characteristics model and the attendant job diagnostic survey. South African Journal of Business Management, 32(1), 11-34.

Bulan, H. F., Erickson, R. J., \& Wharton, A. S. (1997). Doing for others on the job: The affective requirements of service work, gender, and emotional well-being. Social Problems, 44(2), 235-256. http://dx.doi.org/http://dx.doi.org/10.2307/3096944 
Buys, M. A., Olckers, C., \& Schaap, P. (2007). The construct validity of the revised job diagnostic survey. South African Journal of Business Management, 38(2), 31-37.

Carmeli, A., \& Weisberg, J. (2006). Exploring turnover intentions among three professional groups of employees. Human Resource Development International, 9(2), 191-206. http://dx.doi.org/10.1080/13678860600616305

Cho, S., Johanson, M. M., \& Guchait, P. (2009). Employees intent to leave: A comparison of determinants of intent to leave versus to stay. International Journal of Hospiatlity Management, 28(3), 374-381. http://dx.doi.org/http://dx.doi.org/10.1016/j.jhm.2008.10.007

Colbert, A. E., \& Kwon, I. W. G. (2000 ). Factors related to the organizational commitment of college and university auditors. Journal of Managerial Issues, 12(4), 484-503.

Dawley, D., Houghton, J. D., \& Bucklew, N. S. (2010). Perceived orgaizational support and turnover intention: The mediating effects of personal sacrifice. The Journal of Social Psychology, 150(3), 238-257. http://dx.doi.org/10.1080/00224540903365463

Dunham, R. B., Grube, J. A., \& Casteneda, M. B. (1994). Organizational commitment: The utility of an Integrative definition. Journal of Applied Psychology, 79(3), 370-380. http://dx.doi.org/http://psycnet.apa.org/doi/10.1037/0021-9010.79.3.370

Hackman, J. R., \& Oldham, G. R. (1975). Development of the Job Diagnostic Survey. Journal of Applied Psychology, 60(2), 159-170. http://dx.doi.org/10.1037/h0076546

Hom, P. W., \& Griffeth, R. (1991). Structural equations modeling test of a turnover theory: Cross-sectional and longitudinal analyses. Journal of Applied Psychology, 76(3), 350-366. http://dx.doi.org/http://psycnet.apa.org/doi/10.1037/0021-9010.76.3.350

Igbaria, M., \& Greenhaus, J. H. (1992). Determinants of MIS employees' turnover intentions: A structural equation model. Communications of the ACM, 35(2), 34-49. http://dx.doi.org/10.1145/129630.129631

Iverson, R. D., \& Buttigieg, D. M. (1999). Affective, normative and continuance commitment: Can the 'right kind' of commitment be managed? Journal of Management Studies, 36(3), 307-333. http://dx.doi.org/10.1111/1467-6486.00138

Lee, Y. J., \& Kim, K. B. (2008). Experiences of Nurse turnover. Journal of Korean Academy of Nursing, 38(2), 248-257. http://dx.doi.org/10.4040/jkan.2008.38.2.248

Lynn, S. (2004). Antecedents and consequences of organizational commitment to accounting organizations. Managerial Auditing Journal 19(7), 945-955. http://dx.doi.org/10.1108/02686900410549457

McGee, G. W., \& Ford, R. C. (1987). Two (or more?) dimensions of organizational commitment: Reexamination of the affective and continuance commitment scales. Journal of Applied Psychology, 72, 638-642. http://psycnet.apa.org/doi/10.1037/0021-9010.72.4.638

Meyer, J. P., \& Allen, N. J. (1991). A three-component conceptualization of organizational commitment: Some methodological considerations. Human Resource Management Review, 1, 61-98. http://dx.doi.org/10.1016/1053-4822(91)90011-Z

Meyer, J. P., \& Allen, N. J. (1997). Commitment in the workplace: Theory, Research and Application (Vol. 2). Thousand Oaks, CA: Sage.

Mobley, W. H., Horner, S. O., \& Hollingsworth, A. T. (1978). An evaluation of precursors of hospital employee $\begin{array}{lllll}\text { turnover. Journal of } & \text { Applied }\end{array}$ http://psycnet.apa.org/doi/10.1037/0021-9010.63.4.408

Mowday, R. T., Porter, L. W., \& Steers, R. M. (1982). Employee-Organization linkages: The psychology of commitment, absenteeism, and turnover: Academic Press: New York.

Ozturk, A. B., Hancer, M., \& Im, J. Y. (2014). Job characteristics, job satisfaction and organizational commitment for hotel workers in Turkey. Journal of Hospitality Marketing and Management, 23, 294-313. http://dx.doi.org/10.1080/19368623.2013.796866

Price, J. L. (1999). Introduction to the special issue on employee turnover. Human Resource Management Review, 9(4), 387-395. http://dx.doi.org/10.1016/S1053-4822(99)00026-1

Robbins, S. J. (1999). Organizational Behavior (9th ed.). Prentice Hall Publications.

Schuster, F. E. (2002). Employee- centered management: A strategy for high commitment and involvement. Westport, Conn: London Quorum Books. 
Shore, L. M., \& Tetrick, L. E. (1991). A construct validity study of the survey of percieved organizational support. Journal of Applied Psychology, 76(5), 637-643. http://dx.doi.org.10.1037/0021-9010.76.5.637

Somers, M. J. (1995). Organizational commitment, Turnover and Absenteeism: An examination of direct and Interaction Effects. Journal of Organizational Behavior, 16(1), 49-58. http://dx.doi.org/10.1002/job.4030160107

Steers, R. M. (1977). Antecedents and outcomes of organizational commitment. Administrative Sciences Quarterly, 22, 46-56.

Thompson, K. R., \& Terening, W. D. (1983). Job-type variations and antecedents to intention to leave: A content approach to turnover. Human Relations, 36(7), 655-681. http://dx.doi.org/10.1177/001872678303600705

Vandenberghe, C., \& Panaccio, A. (2012). Perceived sacrifice and few alternatives commitments: The motivational underpinnings of continuance commitment's subdimensions. Journal of Vocational Behavior, 81(1), 59-72. http://dx.doi.org/10.1016/j.jvb.2012.05.002

\section{Copyrights}

Copyright for this article is retained by the author(s), with first publication rights granted to the journal.

This is an open-access article distributed under the terms and conditions of the Creative Commons Attribution license (http://creativecommons.org/licenses/by/3.0/). 